\title{
Gender Mainstreaming Critiques: Signposts or Dead Ends?
}

\section{Kirsty Milward, Maitrayee Mukhopadhyay and Franz F. Wong}

\begin{abstract}
An enduring legacy of the Beijing conference, gender mainstreaming has been widely implemented and widely critiqued since the 1990s. But the basis of these critiques has changed over time: this article charts a typology of critique approaches. It shows how the central problem is diagnosed variously as the loss of the political dimensions of gender in the course of mainstreaming; or technical shortcomings; or the gendered nature of organisations as the causes of technical failure. For others, the problem has been the failure to scrutinise the connection between gender mainstreaming and changes in gender relations in women's real lives. More recently, another group asserts that the trajectory of gender mainstreaming is simply part of the much broader logic of neoliberal governance. Understanding the technologies of power that shape a feminist practice suitable for the governance institutions into which it is inserted can help guide future feminist engagement.
\end{abstract}

\section{Introduction - the gender mainstreaming trajectory}

Writing this in the midst of 2015, UN Women and other agencies are immersed in the 'retrospective' called for by the twentieth anniversary of the Fourth World Conference on Women, and of commitments made in the Beijing Declaration and the Platform for Action (BPfA). While significant progress on gender equality has been made over these 20 years on some counts most commentators would agree that the Beijing process promised much more, and a faster pace of change than has taken place in most sectors.

Gender mainstreaming was perhaps the most tangible and widely dispersed legacy of that iconic conference and became the principle strategy by which governments and development organisations set out to take the BPfA agenda forward. Despite great optimism, 20 years later it is difficult to find any review of gender mainstreaming which has more than a few positive aspects to report among a litany of failures. Gender mainstreaming has taken many forms, and has been rolled out in a variety of organisations from multilaterals, to governments, to small and large non-governmental organisations (NGOs). Yet critiques and reviews are almost universally negative, and several commentators question the viability of gender mainstreaming, seeing it as an irredeemably failed strategy (Brouwers 2013; Sandler 2005).
This article is not about what went wrong with gender mainstreaming or why. Rather it categorises the critiques of gender mainstreaming, spanning a period of 15 years, according to the main approaches taken. Although most agree that gender mainstreaming has had limited success, they diagnose the problems differently. Our aim is to reveal not only how understandings of gender mainstreaming have changed over time but also to show that the questions regarding the limited success of this project have changed. We do this because we feel that future feminist engagements with development institutions cannot be about 'doing more of the same better' but that these strategies need to radically change.

\section{The 'lost politics' analysis}

The most common approach adopted in the early reviews of gender mainstreaming was a profound sense of the loss of feminist political objectives in the process of mainstreaming. How this loss is described varies, but most describe how the transformative aim of gender mainstreaming is lost by trying to make the approach more palatable in order to be taken on by development organisations and governments.

The arguments put forward in this type of analysis are 'deficit' arguments: gender mainstreaming fails because it loses vital parts of the agenda as it is inserted into institutions. Concepts that were crucial parts of the package become split off and delinked.

IDS Bulletin Volume 46 Number 4 July 2015 (c) 2015 The Authors. IDS Bulletin @ 2015 Institute of Development Studies Published by John Wiley \& Sons Ltd, 9600 Garsington Road, Oxford OX4 2DQ, UK and 350 Main Street, Malden, MA 02148, USA 
For example, at a KIT conference organised to critically review the achievements of gender training it was emphasised that the terminology of 'gender' quickly became separated from its feminist roots and emptied of its social transformatory content. Gender knowledge in the mainstreaming processes became disconnected from its change implications, obscuring thereby the political nature of the change sought by feminists. Gender work became disconnected from any personal commitment to feminism and has been allowed to become a 'performance' (KIT 2007).

A number of commentators note that it was the feminist advocates entering development institutions in the name of mainstreaming who experienced this splitting up of the concepts and meanings associated with gender most acutely. Mukhopadhyay, in an analysis of how gender mainstreaming has managed to substantially sideline most of the gender concepts, notes that 'the challenge that feminist advocates in development have faced and continue to face is that their work straddles both worlds - the technical and political - but the development business only tolerates the technical role' (Mukhopadhyay 2006: 6).

Roggeband (2014) shows how the pioneering role of the Dutch government in the 1990s in bringing a gender perspective to development cooperation was undermined by the adoption of a mainstreaming approach. The early successes were made possible because of the strong mobilising network of activists and experts in the Netherlands, both in and outside institutions, with close ties to international feminism. This mobilisation was gradually dismantled as Dutch development organisations rapidly and extensively adopted gender mainstreaming strategies, got busy innovating methods and tools and creating new expertise. The political thrust that came from the voluntary involvement and collaboration between activists, experts and senior staff members of the development ministry was sidelined by the gender mainstreaming approach. In the process feminists got shut out from the policymaking process and doing gender became a professionalised, funded project of government.

The overall claim is that as 'gender' has been absorbed into development organisations and governments in the gender mainstreaming process, its meaning has been substantially changed. The major direction of change was towards a technicalised understanding of the process required to achieve greater gender equality: toolkits and procedures within bureaucracies meant to ensure the entry of gender analysis into [all] policies and projects.

\section{The 'technical deficit' analysis}

So while the political dimensions of the journey to gender equality were, according to many, left by the roadside, the technical dimensions to the process of gender mainstreaming evolved rapidly. But even in this area of gender mainstreaming where work developed fast, critiques describing the gaps and failures of technical inputs were also frequent.

Evaluations scrutinised the success or failure of establishing gender units; how far these actually differed from the earlier Women in Development (WID) units or suffered from the same isolation; the extent to which these and gender experts were able to reach into and influence the activities and staff of different departments; the degree to which gender perspectives and analysis had been integrated in project and programme plans and monitoring; and the extent to which gender issues were included in budgeting (see variously AfDB 2011; UNDP 2006; Watkins 2004).

An overview of thematic gender evaluations for the African Development Bank (AfDB) (2011), for example, focused on leadership, accountability and incentives, funding, new procedures and practices, consistent recording and dissemination of results and lessons, and the degree to which gender equality was seen as contributing to or competing with the drive for more effective aid. The areas for action were identified out of an analysis of the technical shortcomings of mainstreaming processes in each of these areas.

Like the AfDB evaluation, other reviews using this approach found that gender units were weak and underfunded; that gender experts were resented; that gender mainstreaming had not made much difference to activities undertaken; and that integration into project plans was at best patchy and frequently 'tacked on'. The evaluation of mainstreaming in the United Nations Development Programme (UNDP 2006: iii), for example, identifies the following technical deficits: 'UNDP has not adopted clearly defined goals, nor dedicated the resources necessary to set and achieve them. There is a lack of systemic approaches, leadership and commitment at the highest levels and of capacity at all levels'. It therefore also identifies technical solutions to rectify these: 'The organisation not only needs to establish a new and stronger institutional structure, but also to demonstrate leadership; articulate a vision; set goals, benchmarks and performance standards at the highest levels; and allocate core administrative and programme resources' (2006: iii). 
For some reviews, such as Moser and Moser (2005), the deficit is identified in the disjuncture between policy and practice as the policy fails to get properly implemented. The solution is often identified as 'more of the same but better', i.e. trying to formulate better tools for better mainstreaming. The analysis in this approach was usually based on identifying missing 'inputs' critical to mainstreaming, such as leadership, commitment, resources, training, policies, etc. (Prügl and Lustgarten 2006).

\section{The 'gendered organisation' analysis}

While the identification of technical deficits did not generally succeed in bringing back the 'lost political' dimension, it did necessitate the sharpening of analysis. Understanding and rectifying technical deficits required explaining why mainstreaming processes appeared to be blocked. By developing explanations for this, a further dimension was brought into focus: that of the gendered nature of organisations. Thus, seeking an understanding of mainstreaming as a technical process brought through the substantial benefit of ushering in an analysis of the organisations and institutions implementing mainstreaming. This perspective greatly helped in increasing the theorising and understanding of the gendered nature of organisational practices, procedures, routines and cultures.

Several bodies of work contributed to this analysis and suggested approaches to improving the gender profile and cultures of organisations. For example, the collection of writing brought together by Goetz (1997: 3) addressed the 'institutional politics of pursuing feminist policy ambitions' and analysed organisational resistance to change. The analysis examines the persistent political marginalisation of women's views on the development process, especially at the level of development planning in institutions such as state bureaucracies, development organisations, multilaterals and NGOs. It proposes a 'gendered archaeology' approach to understand how organisations produce gender differences through their structures and everyday practices. Developing these ideas, Rao, Rieky and Kelleher (1999) bring together writing analysing the institutional barriers to gender equality and put forward methodologies for uncovering the hidden values and cultures the deep structure - of organisations in order to stimulate new, gender-equitable ways of working.

These early accounts of the gendered nature of organisations suggest directions for mainstreaming which, while involving activity radically different from current practice, nevertheless leave intact the possibility of gender mainstreaming as a meaningful strategy. Later studies, on the other hand, are less optimistic about the possibility of changing organisations into vehicles which could implement gender equality strategies: Benshop and Verloo (2006), for example, in a review of mainstreaming within one ministry in Belgium, found that, despite attempts to circumvent some organisational biases, these were in reality deep-seated, involving complex power structures and social relations. They concluded that a gender mainstreaming process would not succeed in transformation because 'the necessity for compromise with existing attitudes hinders its transformative potential' (2006: 31).

\section{The 'lost outcomes' analysis}

This group of analysis refers to losing sight of the results achieved on the ground because of over-absorption in the internal strategy and organisational dynamics of mainstreaming.

\subsection{Failure to scrutinise external change}

In most reviews, insights into changes in gender relations in the lives of women 'in the world' brought about by mainstreaming are barely even sought. Gender mainstreaming in development organisations was envisaged as a two-part process. First, as a process that would raise awareness internally on gender issues leading to policy development and planning procedures to incorporate gender analysis. Second, the actual implementation of gender-aware programmes.

The observation of this 'lost outcomes' analysis is that the second of these aspects - initiatives that contribute to gender equality at programme level among beneficiaries - have been 'lost'. 'Lost' might mean either that they did not happen, or that attempts to evaluate these in relation to the technical structural inputs for gender mainstreaming were absent. Like Brouwers (2013), several critics observe that many organisations have applied a technical gender mainstreaming strategy and also addressed some of the ways in which their organisation's systems and functions reproduced gender bias, but have not properly reviewed how these internal processes are related to the impacts of programmes applied externally. The UNDP gender mainstreaming evaluation (2006) acknowledges the lack of this dimension to their study, and says that this limits the frame of reference for what was evaluated at country level to 'the extent to which attention is accorded to gender relations' (2006: 8). 


\subsection{Failure to cause external change}

Brouwers (2013) also claims more than this: that attention to organisational and procedural issues demanded by gender mainstreaming have absorbed the energy and time of feminist activists such that the opportunity cost has been significant, and damaging, to the project of women's rights. She points out that 'development agencies pursue a [gender mainstreaming] strategy which itself has consumed all attention at the cost of tangible action to solve real problems' (2013: 4). Meier and Celis (2011) concur that the problem is not simply that gender equality and empowerment objectives are not generally assessed in evaluations of gender mainstreaming in relation to women's real lives, but that gender mainstreaming processes have dropped initiatives that address these altogether. This has blurred the objectives of gender mainstreaming and reduced it to procedural detail (2011: 471).

Thus in this 'lost outcomes' analysis we see again the disconnect between gender mainstreaming and gender equality and empowerment objectives that was clearly evident in the earlier 'lost politics' analysis. A preparatory study for an evaluation of gender equality and women's empowerment in the Department for International Development (DFID) in 2006 supports this perspective, stating that it is not simply a lack of ability to evaluate the connection between gender mainstreaming and gender equality impacts that is the problem, but that where evidence is available, there is little to suggest changes to gender inequality: 'available evidence... suggests the benefits of gender mainstreaming and impacts on gender equality are at best embryonic and at worst still to become visible' (Watkins 2004: 5).

For gender equality ministries applying mainstreaming policy 'at home', outcomes beyond the internal organisational changes have to be reported to the electorate/citizens whose vote counts as an accountability mechanism. For overseas development ministries, however, the electorate and 'beneficiaries' of outcomes are different groups. Outcomes have to be explained to a domestic audience and not to the 'beneficiaries' leading increasingly to measurements ensuring the buy-in of this audience, for example, value for money. Eyben (2013) explains how the promotion of the results-and-evidence agenda among bilaterals, following Duffield (2002), is a 'performance of the will to govern' on display for a domestic audience. With accountability drivers such as these in operation which do not account to beneficiaries, it is relatively easy to side-line the issue of real outcomes that make a difference to gender relations in 'beneficiary' countries.
Whereas most reviews are critical of the project of gender mainstreaming and what it is able to achieve, a growing body of research suggests that the gender discourse has been mainstreamed and institutionalised in policymaking institutions. However, the form that institutionalisation has taken is not what feminists would have wanted, in that feminist aspirations for social transformation have remained unfulfilled (Mukhopadhyay 2014; Eerdewijk 2014; Wong 2013). There is, as Halley et al. suggest,

the incremental but by now quite noticeable installation of feminists and feminist ideas in actual legal-institutional power. It takes many forms, and some parts of feminism participate more effectively than others; some are not players at all. Feminists by no means have won everything they want - far from it - but neither are they helpless outsiders (2006: 340).

Thus, instead of asking why the gap remains between the intention of development organisations to mainstream gender and their inability to implement this intent, this group of reviews sees this so-called gap as being characteristic of the institutionalisation process itself and not evidence of failure or partial fulfilment. Rather than ask what has gone wrong, feminist enquiry is directed towards revealing the dominant set of practices and technologies of power that structure and shape the process and produce a feminist praxis suitable for these institutions. Whereas the 'lost politics' reviews struggled to understand why the technical work of gender mainstreaming in the form of tools, frameworks, training manuals, etc. was acceptable and the political message was not, the new forms of enquiry help explain that this disallowance is in itself intensely political; its end product being our subversive complicity in wider projects of governance.

\subsection{Mainstreaming as governance strategy}

In Prügl and Lustgarten's (2006) review of the gender mainstreaming processes of UNDP, the World Bank and the International Labour Organization (ILO) the focus is not on whether gender mainstreaming has 'failed', but as a 'site around which global gender politics operate [where it] takes on meaning through organizational processes and politics' (2006: 54). They seek to understand the patterns of changing meaning of gender concepts as they enter these institutions, and find in general that they become aligned with pre-existing objectives and frameworks already 
driving the organisation: in the World Bank, for example, they find an adjustment of 'feminist arguments to the logics of liberal economics' while also a tendency to 'isolat[e] gender analysis from finance and macroeconomic interventions' (2006: 64).

Other studies have also described 'gender myths' (Cornwall, Harrison and Whitehead 2008)the various stories and leitmotifs concerning understandings of women which provide a fit with policy objectives of global development and aid institutions - such as the primacy of economic growth. These 'stories' include the myth of femaleheaded households as 'the poorest of the poor' (Chant 2008) and of African women as 'poor, powerless and pregnant' (Win 2008).

Halley et al. (2006) name this form of feminist engagement whereby feminists and feminist ideas are gradually installed in actual legal-institutional power as governance feminism. Prügl (2011) shows that it involved the governmentalisation of feminist knowledge, i.e. the rendition of feminist knowledge for the purposes of government. Governmentality refers here to Foucault's conceptions about the act of rule and the exercise of power by a 'diversity of forces and groups that have, in heterogeneous ways, sought to regulate the lives of individuals' (Miller and Rose 1990: 3). Governmentality is not necessarily about imposing constraints but rather about creating the subject most suited for specific policies which is achieved not by coercion but through the use of technologies or actual mechanisms, 'the ensemble of institutions, procedures, analyses [and] tactics that allow the exercise' of power (Foucault 1991: 102-3) and construct the reality that has to be governed.

Gender was one such subject and the 'third world woman' a category that inter-governmental and national authorities sought to govern in the wake of the drive for accelerated global economic integration and globalisation in the last two decades; a period of intense activity on gender mainstreaming since Beijing 1995. In making gender governable, 'truths' about women's position and situation and about gender relations have been generated, contributed to by bodies of knowledge, the formalisation of expertise on gender, the generation of information and the construction of intervention technologies, training, procedures and tools (Mukhopadhyay 2014). Feminists, gender experts, researchers inside and outside institutions are participants in these projects of government. Gender experts, one force in the diversity of forces seeking to regulate the lives of individuals, draw their authority not from any political position but from their ability to make feminist knowledge into programmes of government (Prügl 2011).

Harcourt's (2006) analysis of the activism of international women's rights movements to find a place in global development institutions is very instructive. It shows that whereas feminist activism had a great deal of impact in creating the acceptability of the gender and development discourse in global institutions for development, the process of inserting this knowledge via UN official texts, background reports, statistics and evidence inevitably codified and simplified the vastly different experiences of women around the world. It produced the generic gendered female body - the poor woman with an expertly understood set of needs and rights that institutions have to programme for, the female subject most suited for the policies of international development.

Prügl (2011) goes further by unpacking gender mainstreaming as a prototypical governmental technology embedded in an apparatus of gender. This apparatus does not have a particular intention, she suggests, but has only one interest which is to govern. Embracing a logic of bureaucratic governmentality, gender mainstreaming targets bureaucrats who integrate the mandate for gender equality while working to advance governmental ends, such as economic growth, free trade, security, etc. In the process neoliberal logics do not constitute the means to governing gender but rather define its ends. For example, efforts to mainstream gender into the policies of the World Bank have led to programmes encouraging men to share domestic and care responsibilities in private households at the expense of public investment into the care economy.

Eyben (2013) analyses 'development artefacts' such as the 'results' and 'evidence' artefacts, increasingly dominant in development aid, as technologies of power that 'produce' the results that the political and bureaucratic arenas want. They are 'implemented and enforced by authority, but often also internalised so that no obvious external control is required...' (2013: 8). Such artefacts limit - sometimes severely - the 'politico bureaucratic space' for transformative change. Eyben suggests, like Prügl, that the importance of the analysis is to be able to expose the operations of power 'working invisibly to make us concur with what we know are inappropriate methods for designing and assessing programmes with multiple pathways of change' (2013: 26). 


\section{Conclusion: where do we go from here?}

The first critiques of gender mainstreaming took a 'microscope' perspective on the details of mainstreaming to try and untangle what had gone wrong and where. The purpose was to rectify these issues so that mainstreaming could be put back on track. This is broadly true of the 'lost politics' analysis, the 'technical deficit' analysis, and the 'gendered organisation' approach. All of these approaches brought vital insights to a rapidly evolving process of understanding the institutions into which gender knowledge was being inserted. But by focusing on details, these approaches lost sight of the 'bigger picture'.

The 'lost outcomes' analysis was a step towards re-inserting that bigger picture, by specifying the need to re-connect with the reality of how and whether development interventions contribute to gender equality. But the 'governmental technologies' analysis re-asserts the bigger picture much more clearly, by insisting that the trajectory of gender mainstreaming must be seen as only part of the much broader logic of the operations of power and of the wider projects of neoliberal governance.

\section{References}

AfDB (African Development Bank) (2011)

'Mainstreaming Gender Equality: Emerging Evaluation Lessons', Operations Evaluation Department, Evaluation Insights 3: 1-8

Benshop, Y. and Verloo, M. (2006), 'Sisyphus' Sisters: Can Gender Mainstreaming Escape the Genderedness of Organizations?', Journal of Gender Studies 15.1: 19-33

Beveridge, F. and Nott, S. (2002) 'Mainstreaming: A Case for Optimism and Cynicism', Feminist Legal Studies 10: 299-311

Brouwers, R. (2013) Revisiting Gender Mainstreaming in International Development: Goodbye to an Illusionary Strategy, Working Paper 556, The Hague, Netherlands: Institute of Social Studies Chant, S. (2008) 'Dangerous Equations? How Female-headed Households Became the Poorest of the Poor: Causes, Consequences and Cautions', in A. Cornwall, E. Harrison and A. Whitehead (eds), Gender Myths and Feminist Fables: The Struggle for Interpretive Power in Gender and Development, Oxford: Wiley Blackwell

Cornwall, A.; Harrison, E. and Whitehead, A. (2008) Gender Myths and Feminist Fables: The Struggle for Interpretive Power in Gender and Development, Oxford: Wiley Blackwell

Duffield, M. (2002) 'Social Reconstruction and the Radicalization of Development: Aid as a Relation
So what is the future, not just of gender mainstreaming, but rather the wider project of feminist engagement with governance institutions? An option that has always been there is to question whether this is and should be the principal site of feminist engagement (Beveridge and Nott 2002) or whether to direct energy to other sites. But as we know, most feminisms are not governance feminism. Nevertheless, the reality of governance feminism calls for a reinvention of strategies of engagement that are able to expose the workings of power that make us complicit with ways of working, thinking, and reviewing development that are inappropriate and harmful. The important thing is to remember that projects of government are never complete. The most well thought out programmes never actually reach fruition and have unplanned unintended consequences. Thus, governing does not have a totalising effect and there are always insurrections undoing the perfect governmental project. Taking this cue, future feminist engagement has to be both about the politics of refusal, and of knowledge production that is subversive which 'defies reinscription in the mainstream’ (Mukhopadhyay 2014: 316).

of Global Liberal Governance', Development and Change 33.5: 1049-71

Eerdewijk, A. (2014) 'The Micropolitics of Evaporation: Gender Mainstreaming Instruments in Practice', Fournal of International Development 26: 345-55

Eyben, R. (2013) 'Uncovering the Politics of "Evidence" and "Results". A Framing Paper for Development Practitioners', paper prepared for conference on Big Push Forward, April, http:/ /bigpushforward.net/wp-content/ uploads/2011/01/The-politics-of-evidence-11April-20133.pdf

Foucault, M. (1991) 'Governmentality', in G. Burchell, G. Gordon and P. Miller (eds), The Foucault Effect: Studies in Governmentality, Chicago IL: University of Chicago Press

Goetz, A.M. (ed.) (1997) Getting Institutions Right for Women in Development, New York NY: Zed Books

Halley, J.; Kotiswaran, P.; Shamir, H. and Thomas, C. (2006) 'From the International to the Local in Feminist Legal Responses to Rape, Prostitution/Sex Work, and Sex Trafficking: Four Studies in Contemporary Governance Feminism', Harvard Fournal of Law \& Gender 29: 335-423

Harcourt, W. (2006) The Global Women's Rights Movement: Power Politics Around the United Nations and World Social Forum, Civil Society and Social Movements Programme Paper 25, Geneva: UNRISD 
KIT (Royal Tropical Institute) (2007) 'Revisiting Studies and Training in Gender and Development - The Making and Re-making of Gender Knowledge', report from the international KIT conference, 14-16 May

Meier, P. and Celis, K. (2011) 'Sowing the Seeds of its Own Failure: Implementing the Concept of Gender Mainstreaming', Social Politics 18.4: 469-89

Miller, P. and Rose, N. (1990) 'Governing Economic Life', Economy and Society 19.1: 1-31

Moser, C. and Moser, A. (2005) 'Gender Mainstreaming since Beijing: A Review of Success and Limitations in International Institutions', Gender and Development 13: 11-22

Mukhopadhyay, M. (2014) 'Mainstreaming Gender or Reconstituting the Mainstream? Gender Knowledge in Development', Fournal of International Development 26.3: 356-67

Mukhopadhyay, M. (2006) 'Mainstreaming Gender or Streaming Gender Away? Feminists Marooned in the Development Business', in A. Cornwall, E. Harrison and A. Whitehead (eds), Feminisms in Development: Contradictions, Contestations and Challenges, London: Zed Books

Prügl, E. (2011) 'Diversity Management and Gender Mainstreaming as Technologies of Government', Politics and Gender 7: 71-89

Prügl, E. and Lustgarten, A. (2006) 'Mainstreaming Gender in International Organizations', in
J.S. Jaquette and G. Summerfield (eds), Women and Gender Equity in Development Theory and Practice: Institutions, Resources, and Mobilization, Durham NC: Duke University Press

Rao, A.; Rieky, S. and Kelleher, D. (1999) Gender at Work: Organizational Change for Equality, London: Kumarian Press

Roggeband, C. (2014) 'Gender Mainstreaming in Dutch Development Cooperation: The Dialectics of Progress', Fournal of International Development 26: 332-44

Sandler, J. (2005) 'Gender Mainstreaming in the Age of Aid Effectiveness', presentation by J. Sandler, UNIFEM to the OECD-DAC Network on Gender Equality, Paris

UNDP (2006) Evaluation of Gender Mainstreaming in $U \mathcal{N D P}$, New York NY: UNDP Evaluation Office

Watkins, F. (2004) DFID's Experience of Gender Mainstreaming: 1995 to 2004, London: UK Department for International Development Win, E. (2008) 'Not Very Poor, Powerless or Pregnant. The African Woman Forgotten by Development', in A. Cornwall, E. Harrison and A. Whitehead (eds), Gender Myths and Feminist Fables: The Struggle for Interpretive Power in Gender and Development, Oxford: Wiley Blackwell

Wong, F. (2013) 'Following the Commitment:

Development NGOs and Gender Mainstreaming - The Case of Oxfam GB', Doctoral thesis, University of Sussex 